Ethos: Jurnal Penelitian dan Pengabdian Masyarakat, Vol 10 No.1, Januari 2022: 19-30

\title{
Pemanfaatan Eceng Gondok (Eichornia Crassipes) Dan Limbah Pertanian Untuk Persediann Pakan Ternak Dan Biokompos Berbasis Teknologi Fermentasi
}

\author{
${ }^{1}$ Novi Arfarita, ${ }^{2}$ Anik Malikah, ${ }^{3}$ Djuhari \\ ${ }^{1,3}$ Fakultas Pertanian, Universitas Islam Malang, Indonesia \\ ${ }^{2}$ Fakultas Ekonomi, Universitas Islam Malang, Indonesia \\ email: '1arfarita@unisma.ac.id/arfarita@yahoo.com
}

\begin{abstract}
Water hyacinth causes environmental problems in the Selorejo Reservoir due to its rapid growth. This activity aims to introduce fermentation-based technology to farmer groups (klomtan) in the use of water hyacinth as animal feed and compost, reduce environmental impact and increase its economic value. The methods used are (1) Organizing education and training on zero waste product technology through the manufacture of silage and bio compost for water hyacinth weeds; (2) Provide a special place for the manufacture of silage and bio compost; (3) Strengthening klomtan institutions with production and marketing management training; (4) Assist in production monitoring. This program has achieved the following targets: (1) Farmers and ranchers can adopt a zero-waste technology package to increase livestock productivity and agricultural products; (2) Increasing the awareness and ability of klomtan to utilize agricultural waste and water hyacinth weeds; (3) Institutional strengthening of the Karya Makmur and Lestari Jaya Makmur groups so that they can become examples of farming communities in their villages. The results of this activity showed an increase in the knowledge of group members by $85 \%$ of the technology offered. Continuous assistance needs to be carried out because fermentation technology is influenced by various factors so that it is not easily applied by klomtan.
\end{abstract}

Keywords: Fermentation technology, Silase, Biokompos, Zero Waste Product

\begin{abstract}
Abstrak. Eceng gondok menyebabkan masalah lingkungan di Waduk Selorejo karena pertumbuhannya yang cepat. Tujuan kegiatan ini untuk mengenalkan teknologi berbasis fermentasi kepada kelompok tani (klomtan) dalam pemanfaatan Enceng Gondok sebagai pakan ternak dan kompos, mengurangi dampak lingkungan dan meningkatkan nilai ekonominya. Metode yang digunakan adalah (1) Melakukan penyuluhan dan pelatihan teknologi zero waste product dengan memberikan pelatihan pembuatan silase dan biokompos gulma enceng gondok; (2) Menyediakan tempat khusus pembuatan silase dan biokompos; (3) Penguatan kelembagaan klomtan dengan pelatihan manajemen produksi dan pemasarannya; (4) Melakukan pendampingan monitoring produksi. Kegiatan ini telah mencapai target: (1) Petani dan peternak mampu mengadopsi paket teknologi zero waste product untuk meningkatkan produktivitas ternak dan hasil pertanian; (2) Tumbuhnya kesadaran dan kemampuan klomtan untuk memanfaatkan limbah pertanian dan gulma enceng gondok; (3) Penguatan Manajemen Kelembagaan klomtan Karya Makmur dan Lestari Jaya Makmur agar dapat menjadi contoh masyarakat tani-ternak di desanya. Hasil kegiatan ini menunjukkan peningkatan pengetahuan anggota kelompok sebesar $85 \%$ terhadap teknologi yang ditawarkan. Pendampingan secara terus-menerus perlu dilakukan karena teknologi fermentasi dipengaruhi oleh berbagai faktor sehingga tidak mudah diterapkan oleh klomtan.
\end{abstract}

Kata kunci : Teknologi fermentasi, Silase, Biokompos, Zero Waste Product

\section{Pendahuluan}

Permasalahan

tentang

meningkatnya eceng gondok ditemukan di desa Desa Kaumrejo, Kecamatan Ngantang, Kabupaten Malang yang berdekatan dengan Bendungan Selorejo.
Lahan pertanian petani banyak yang berada di seberang Bendungan Selorejo yang sering terhalang oleh bentangan tanaman eceng gondok (Eichornia crassipes) yang tumbuh memenuhi Bendungan.

Selain permasalahan utama, yakni 
sulitnya mendapatkan pakan ternak pada musim musim kemarau, petani juga menghadapi permasalahan lingkungan, yaitu blooming (petumbuhan yang sangat cepat) enceng gondok yang diakibatkan oleh menigkatnya polutan, bahan pencemar, dan sisa residu pupuk yang memicu pertumbuhannya. Harga hijauan pakan ternak pada musim kemarau juga dapat mencapai lima kali lipat harga normal. Pada kondisi tersebut, di kalangan petani dikenal istilah "sapi makan sapi" (Menjual sapi anakan/sapi yang belum menghasilkan susu untuk membeli pakan ternak).

Pada tahun 2013 telah terjadi blooming yang mencapai 100 hektare dari total luas waduk, yakni sekitar 650 hektare. Sebagai pengelola waduk, Perusahaan Umum Jasa Tirta (PJT) I, kewalahan mengatasinya. Keberadaan eceng gondok yang telah meluas di waduk tersebut kini dirasa mengganggu aktivitas warga sampai saat ini, seperti budi daya ikan di waduk dan gagal panen karena tanamannya diserbu tikus yang bersarang pada eceng gondok (Departemen Perindustrian, 1992). Blooming enceng gondok yang mengganggu aktivitas dan kualitas hidup warga di sekitar waduk, yaitu menyebabkan terganggunya mobilitas warga ke sawah/ladangnya; gagalnya panen disebabkan waduk yang dipenuhi enceng gondok merupakan sarang tikus; terganggunya budi daya ikan di waduk dan mewabahnya penyakit malaria. Mahalnya pupuk pertanian mengakibatkan meningkatnya biaya produksi pertanian dan dampak dari pupuk kimia yang mengakibatkan blooming enceng gondok akan semakin tak tertanggulangi. Masalah yang berikutnya adalah masalah manajemen dan penguatan kelembagaan yang ada pada kelompok petani. Pengaturan kelompok tani Karya Makmur dan Lestari Jaya Makmur dilakukan sangat sederhana, demikian juga pola kerja dan perencanaanya. Secara spesifik, kelompok tani Karya Makmur dan Lestari
Jaya Makmur dalam pengelolaannya yang diterapkan adalah manajemen kekeluargaan. Pada dasarnya, hal itu belum menerapkan prinsip-prinsip manajemen yang semestinya. Hasil pertanian/peternakan biasanya dijual ke tengkulak atau ke pasar tradisional (Pasar Ngantang, Kasembon, Kandangan, Pujon) secara individual. Sistem permodalan belum ada yang menggunakan dari lembaga keuangan.

Seperti yang disampaikan oleh Sittadewi (2007: 209), Eceng gondok (Eichornia crassipes) adalah tanaman pengganggu (gulma) dan invasif yang berasal dari Brazil yang dapat mempercepat pendangkalan perairan sehingga memperbesar kehilngan air dan menurunkan hasil perikanan dalam 1 ha dapat menghasikan biomass sebesar 125 ton (Juliani et al., 2007: 220). Salah satu upaya yang dapat dilakukan untuk mengurangi dan memanfaatkannya adalah dengan membuat pupuk organik (Prihartiningtyas et al., 2020: 114). Pertumbuhannya yang sangat cepat menjadi masalah lingkungan di beberapa tempat di Indonesia, seperti di Martapura-Kalimantan (Prihartiningtyas et al., 2020: 114); Danau Toba (Juliani et al., 2017: 220); Gayamsari-Semarang (Kusrinah \& Hayati, 2016: 27): GowaMakasar (Lestari et al., 2018: 24)

Kegiatan pengabdian pada masyarakat di Universitas Islam Malang sudah lama diselenggarakan oleh dosen dan mahasiswa. Ini merupakan bukti implementasi secara bertahap dari penguasaan ilmu pengetahuan dan teknologi. Beberapa program dilaksanakan dengan cara memanfaatkan dan menerapkan, baik hasil penelitian maupun hasil proses pembelajaran di perguruan tinggi. Pengabdian masyarakat dilakukan secara melembaga di bawah koordinasi LPM Unisma. Salah satunya adalah untuk menyelesaikan permasalahan gulma enceng gondok di Waduk Selorejo, Ngantang ini. Diharapkan, teknologi yang dapat 
diadopsi adalah penerapan teknologi "Zero waste product", yaitu tidak ada yang terbuang dari limbah enceng gondok dan seluruhnya bisa dimanfaatkan untuk bertani dan beternak (Hayashi, 2003). Kepakaran yang diperlukan untuk menyelesaikan persoalan kelompok tani ternak Karya Makmur dan Lestari Jaya Makmur di desa Kaumrejo, Kecamatan Ngantang, Kabupaten Malang yang difokuskan pada program usaha pembuatan silase dan biokompos dengan teknologi zero waste product dan penguatan telah terpenuhi di tim kegiatan ini.

Tujuan dari pengabdian masyarakat ini adalah untuk: (1) Memanfaatkan potensi Eceng Gondok dan Limbah Pertanian yang terdapat dalam jumlah berlimpah di Desa Kaumrejo, Kabupaten Malang, untuk bahan pakan ternak (silase) dan biokompos berbasis Teknologi Fermentasi dengan konsep zero waste product; (2) Mengembangkan dan menyosialisasikan SOP (Standart Operasioanl Prosedure pembuatan silase dan biomopos ke petani mitra; (3) Meningktakan jalinan kerja sama dengan mitra dalam rangka menigkatkan taraf ekonomi masyarakat pedesaaan.

\section{Metode Ilmiah}

\section{Lokasipengabdian kepada masyarakat} Lokasi pengabdian kepada masyarakat ini berada pada Kelompok Tani-Ternak Karya Makmur dan Lestari Jaya Makmur yang berada di Desa Kaumrejo, Kabupaten Malang. Berdasarkan dokumen dari desa tahun 2010-2015, desa ini secara struktural merupakan bagian integral yang tak terpisahkan dari sistem perwilayahan Kecamatan Ngantang. Secara geografis, Desa Kaumrejo terletak di wilayah barat jalur alternatif transportasi barat Kota Malang dengan luas wilayah 590 hektare. Ketinggian desa ini adalah antara 500700 mdpl. Desa Kaumrejo adalah desa jantung Kecamatan Ngantang karena keberadaan Pasar Ngantang dan Kantor Kecamatan serta Perkantoran Pemerintah yang lain seperti PLN, Kantor Pos, Kantor Polisi, Puskesmas, PDAM, dan Koramil berada di dalam wilayah Desa Kaumrejo ini. Jumlah penduduk desa Kaumrejo adalah 5.451 jiwa dengan kepadatan penduduk $923.89\left(\mathrm{~km}^{2}\right)$ (Anonymous, 2013).

\section{Kondisi dan Karakteristik Mitra}

Kedua kelompok tani-ternak mitra 1, masing-masing mempunyai karakter dan kondisi yang berbeda. Kelompok Karya Makmur adalah sebagai mitra dengan deskripsi profil sebagai berikut: anggota dan pengurus rata-rata berusia muda dan mempunyai ternak kambing 65 ekor dengan pola bagi hasil 1:2, yaitu Kelompok Tani : Pemelihara. Karena beranggotakan ratarata berusia muda, kelompok ini mudah mengadopsi teknologi baru. Mereka memiliki pengalaman mengolah enceng gondok menjadi kompos. Kelompok Lestari Jaya Makmur adalah sebagai mitra dengan diskripsi profil, yaitu pengurus dari kalangan pemuda, tetapi anggotanya didominasi orang tua. Mereka mempunyai ternak sapi 5 ekor dan umumnya adalah sebagai petani. Kelompok ini tidak menguasai teknologi, tetapi akan menjembatani komunikasi dengan aparat pemerintah Desa dan PT Jasa Tirta sebagai pengelola Bendungan Selorejo Ngantang.

Saat ini, melihat kondisi penduduk desa Kaumrejo, mata pencaharian utamanya adalah sebagai petani dan peternak. Produksi hasil pertanian dan peternakan sangat tergantung pada kondisi musim. Untuk masa sekarang, yang relatif paling diandalkan sebagai penghasilan keluarga adalah peternakan sapi perah. Adapun usaha tani yang lain dijadikan usaha sampingan. Artinya, usaha tani bercocok tanam tidak dilakukan secara intensif. Hasil produksi susu segar dijual melalui Kelompok Tani Karya Makmur dan Lestari Jaya Makmur 
Tabel 1. Pemetaan Persoalan yang ada pada Kelompok Tani binaan

\begin{tabular}{|c|c|c|}
\hline Mitra & Penguasaan Teknologi & Manajemen \\
\hline $\begin{array}{l}\text { Kelompok Tani } \\
\text { Karya Makmur } \\
\text { (dusun } \\
\text { Prabon I, desa } \\
\text { Kaumrejo) }\end{array}$ & 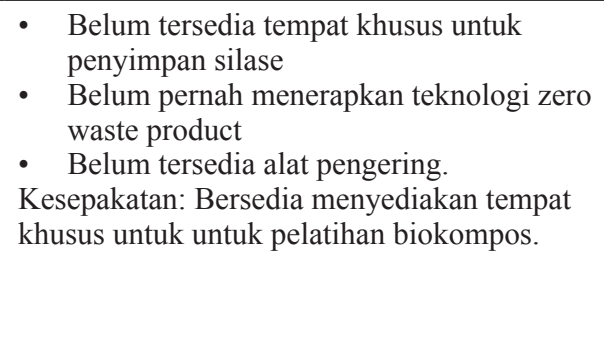 & $\begin{array}{l}\text { - } \quad \text { Rata-rata berusia muda } \\
\text { Memiliki pengalaman pengolahan enceng } \\
\text { gondok menjadi kompos tapi tidak } \\
\text { pengalaman dalam teknologi silase. } \\
\text { Pola manajemen belum tertata dengan } \\
\text { baik dalam penyediaan pakan ternak dan } \\
\text { pemanfaatan potensi lingkungannya untuk } \\
\text { menunjang usaha kelompok tani. } \\
\text { Butuh bantuan inovasi teknologi dan } \\
\text { pemasaran produk. }\end{array}$ \\
\hline $\begin{array}{l}\text { Kelompok } \\
\text { Tani Lestari } \\
\text { Jaya Makmur } \\
\text { (dusun } \\
\text { Gading, desa } \\
\text { Kaumrejo) }\end{array}$ & $\begin{array}{l}\text { - Belum tersedia tempat khusus untuk } \\
\text { penyimpan silase dan biokompos. } \\
\text { Belum pernah menerapkan teknologi zero } \\
\text { waste product } \\
\text { Belum tersedia alat pembuat silase dan } \\
\text { biokompos. } \\
\text { Kesepakatan: Bersedia menyediakan tempat } \\
\text { khusus untuk untuk pelatihan pembuatan } \\
\text { silase }\end{array}$ & $\begin{array}{l}\text { - } \quad \text { Didominasi oleh orang tua. } \\
\text { Belum ada tenaga yang mengetahui dan } \\
\text { terampil dalam menangani gulma enceng } \\
\text { gondok. } \\
\text { - Tidak ada pengalaman dalam berorganisasi } \\
\text { - Tidak mempunyai pengetahuan pemanfaatan } \\
\text { potensi lingkungannya untuk menunjang } \\
\text { usaha kelompok tani }\end{array}$ \\
\hline
\end{tabular}

Sumber: Anonymous (2013) dan observasi langsung melalui wawancara dengan pemuka desa dan ketua klomtan.

atau ke koperasi lain yang menawarkan harga beli yang lebih tinggi.

\section{Rancangan Kegiatan}

Jadwal kegiatan disusun selama kurun waktu 8 bulan dengan 11 jenis kegiatan; dimulai survei awal bulan April 2018 sampai dengan Desember 2021. Kegiatannya terdiri atas kegiatan koordinasi, penyuluhan, rekayasa, pembuatan alat, yaitu mesin pencacah, alat pengatus, dan pembuat konsentrat, pelatihan pembuatan silase dan biokompos, pelatihan manajemen kelembagaan kelompok tani, dan pelaporan. Kemudian, mesin pemeras enceng gondok dan mesin pembuat konsentrat siap digunakan dan diserahterimakan ke kelompok tani. Secara khusus, terdapat kegiatan pembimbingan dan pendampingan langsung untuk memproduksi silase yang bisa dilaksanakan. Analisa laboratorium dilakukan untuk melihat kualitas hasil akhir dari pembuatan silase dan biokompos oleh kelompok tani sampai produksi mandirinya mencapai standar secara pengamatan visual. Rancangan kegiatan disusun seperti yang ditunjukkan pada Gambar 1.

Rancangan kegiatan pembimbingan dan pendampiangan dilakukan dengan beberapa pendekatan sebagi berikut.

a. Sosialisasi kegiatan

Sosialisasi kegiatan kepada kelompok tani Karya Makmur dan Lestari Jaya Makmur di dusun Gading melalui Kepala Desa Kaumrejo tentang pelaksanaan program IbM. Sosialisasi

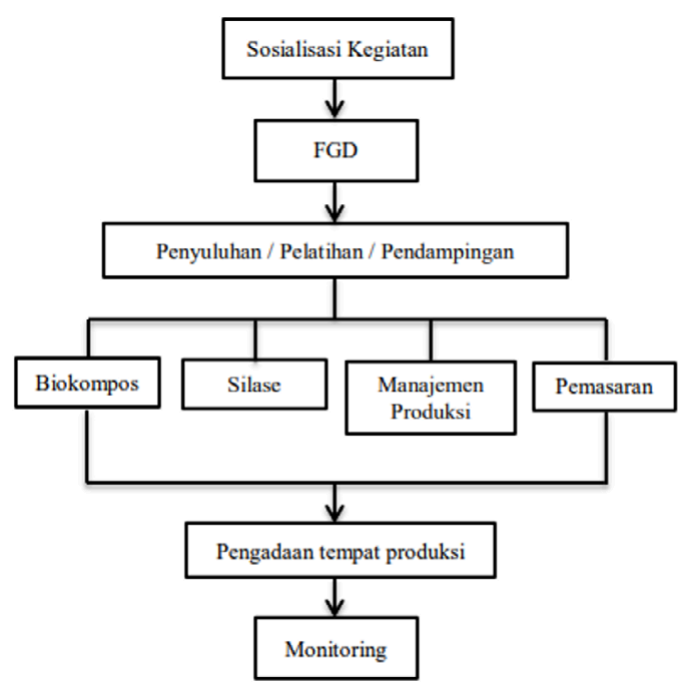

Gambar 1. Rancangan kegiatan pengabdian masyarakat dalam pemanfaatan eceng gondok (eichornia crassipes) dan limbah pertanian untuk silase dan biokompos. 
menyangkut jadwal pelaksanaan, tempat, dan sarana prasarana yang digunakan.

b. Diskusi kelompok/FGD

Diskusi kelompok/FGD ini adalah dalam rangka membahas permasalahan mitra kelompok tani Karya Makmur dan Lestari Jaya Makmur dari Desa Kaum Rejo yang mengacu pada analisis situasi dan telah disepakati bersama oleh ketua kelompoknya masing-masing dan para anggotanya.

c. Penyuluhan/Pelatihan/ Pendampingan

Kegiatan pelatihan meliputi proses pembuatan pakan ternak yang berasal dari gulma enceng gondok yang sejatinya sulit diolah,dengan melalui teknologi fermentasi (silase) dan biokompos yang dapat dilakukan oleh kelompok tani.

d. Pendampingan analisa kualitas pakan ternak silase.

e. Monitoring dan evaluasi terhadap keberhasilan program.

Tujuannya adalah mengukur tingkat keberhasilan program yang telah diterapkan terhadap kelompok tani Teman Sejati di dusun gading dan desa Kaumrejo.

\section{Hasil dan Pembahasan}

Dari hasil sosialsasi dan FGD dengan ketua dan anggota kelompok mitra disepakati beberapa poin penting usulan kegiatan yang berupa:

a. Tim ahli / pendamping / narasumber melakukan penyuluhan dan sosialisasi. Fokus kegiatan penyuluhan ini adalah diseminasi tentang pentingnya teknologi tepat guna dengan konsep zero waste product melalui kegiatan pembuatan silase dan biokompos dari gulma enceng gondok dan limbah pertanian.

Tujuan penyuluhan ini adalah agar peserta dapat mengetahui definisi dan batasan silase dan biokompos, manfaatnya, serta langkah-langkah pembuatannya mulai dari persiapan,

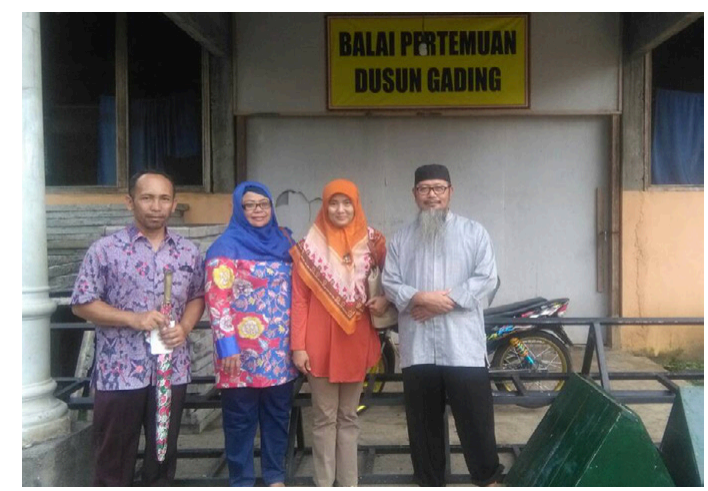

Gambar 2. Kegiatan penyuluhan dan sosialisasi zero waste produk eceng gondok pada klomtan

penyediaan sarana dan prasarana, proses produksi dan fermentasi, dan pengujiannya pada pakan ternak. Oleh karena itu, sebelum praktik pembuatan silase dan biokompos dari enceng gondok dan limbah pertanian, mereka sudah memiliki bekal teori yang cukup memadai. Hal yang dijelaskan dalam penyuluhan adalah limbah pertanian dan gulma enceng gondok dapat diolah menjadi pakan ternak, kemudian kotoran ternak diolah jadi pupuk organik. Ketika musim penghujan, ketersediaan hijauan pakan ternak melimpah, baik yang berupa rumput gajah, limbah tanaman jagung, jerami padi, maupun hijauan limbah tanaman yang lain (termasuk enceng gondok). Semua itu dapat diolah dengan teknologi fermentasi pakan ternak (silase). Hasil olahan tersebut dapat disimpan dalam waktu yang cukup lama sehingga pada saatnya diperlukan dan dapat digunakan. Untuk melihat hasil capaian penyuluhan dilaksanakan pre dan post test kepada peserta penyuluhan.

Hasil dari penyuluhan ini menunjukkan peningkatan terhadap beberapa indikator capaian, seperti yang terdapat pada Tabel 2.

Dari Tabel 2 terlihat bahwa dari keseluruhan indikator capaian kegiatan penyuluhan terdapat peningkatan pengetahuan kelompok tani tentang pengertian konsep zero waste product, eceng gondok sebagai gulma, cara pengendaliannya, nilai ekonomisnya, dan terdapat keinginan kelompok tani untuk 
Tabel 2. Indikator ketercapaian penyuluhan

\begin{tabular}{lcc}
\hline \multicolumn{1}{c}{ Indikator capaian } & Pre test & Post test \\
\hline 1.Pengertian konsep zero waste product & $20 \%$ & $50 \%$ \\
\hline 2.Pemahaman eceng gondok sebagai gulma & $80 \%$ & $90 \%$ \\
\hline 3.Pengetahuan teknologi pengendalian gulma eceng gindok & $30 \%$ & $80 \%$ \\
\hline $\begin{array}{l}\text { 4.Nilai ekonomis eceng gondok untuk pakan ternak (silase) dan pupuk organic } \\
\text { (biokompos) }\end{array}$ & $25 \%$ & $75 \%$ \\
\hline $\begin{array}{l}\text { 5.Keinginan petani untuk mengolah eceng gondok menjadi produk yang lebih } \\
\text { bermanfaat }\end{array}$ & $20 \%$ & $60 \%$ \\
\hline
\end{tabular}

mengolahnya menjadi produk yang lebih bermanfaat sekitar 50 sd $80 \%$.

b. Tim melaksanakan Pelatihan dan Pendampingan pembuatan silase dan biokompos dari enceng gondok dan limbah pertanian (Gambar 3).

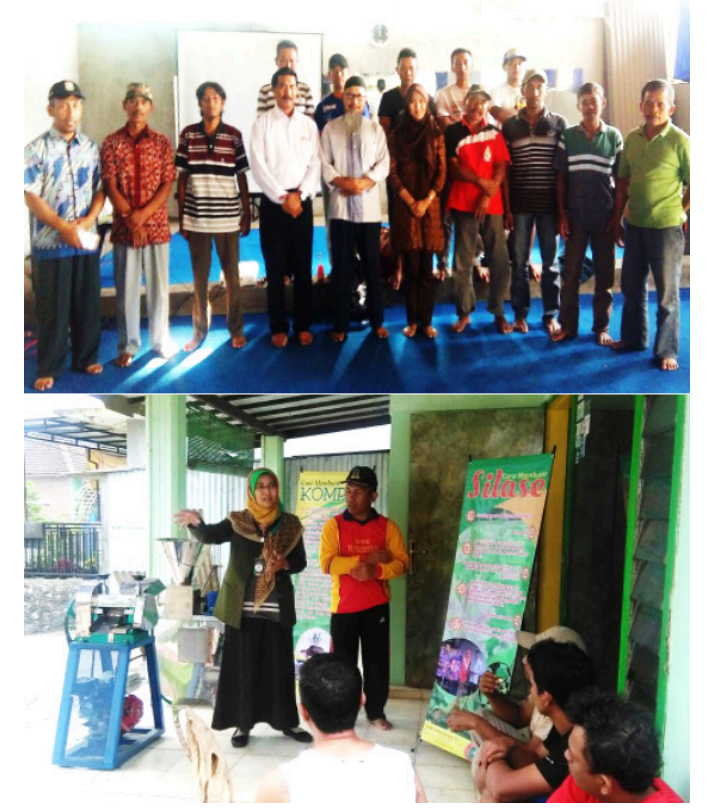

Gambar 3. Kegiatan pendampingan (atas) dan pelatihan (bawah) kelompok tani.

Tujuan pelatihan ini adalah agar anggota kelompok tani dapat menguasai zero waste product sehingga mereka mampu membuat silase dan biokompos secara mandiri. Isi materi yang disampaikan meliputi persiapan alat-alat yang diperlukan antara lain: mesin pencacah, keranjang bambu untuk meniriskan enceng gondok dan limbah pertanian, cangkul, sekop, ember plastik, gembor air, drum, dan kantong plastik besar berwarna hitam. Semua itu disampaikan dalam SOP pembuatan silase dan biokompos yang telah dibagikan kepada petani sebagai berikut.

\section{SOP Pembuatan pakan ternak (Silase)}

Cara membuat silase adalah sebagai berikut: (1) enceng gondok ditiriskan sekurang kurangnya sehari semalam, sebelum kemudian dicacah.; (2) selanjutnya dilakukan pencampuran dengan komposisi dua enceng gondok dengan satu konsentrat (kalau enceng gondoknya $100 \mathrm{~kg}$, konsentratnya 50 kilogram); (3) kemudian ditambahkan tetes tebu sekitar $1-2$ persen; (4) campuran tersebut kemudian diperam sekurang kurangnya 2 minggu dalam wadah kedap udara seperti drum atau kantong plastik dengan tingkat kepadatan 600 kilogram per meter kubik; (5) Setelah itu, pakan dari olahan enceng gondok pun siap digunakan. Sementara itu, bahan dan alat yang dibutuhkan untuk membuat kompos dari limbah organik adalah jerami, rumput-rumputan, kotoran ternak/pupuk kandang (dapat terpisah atau sebagai campuran). Apabila jerami terlalu kering, lakukan perendaman selama 4-6 jam. Peralatan utama adalah mesin pencacah, terpal, dan sekop.

Untuk silase yang berkualitas baik, secara langusng dapat diamati, yakni berbau harum agak manis khas fermentasi silase, tidak berjamur dan tidak menggumpal, tidak busuk atau tidak berbau busuk, warna coklat kehijauhijauan, nilai $\mathrm{pH}$ atau derajat keasaman $4-4,5$. Dengan begitu, kualitas nutrisi secara laboratorium sudah dilakukan. 


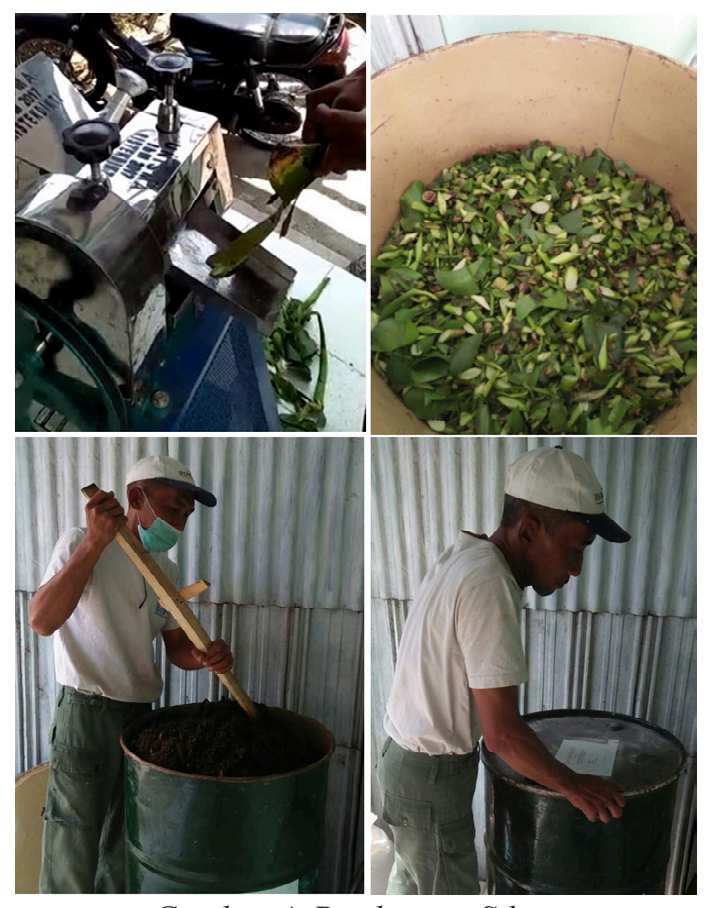

Gambar 4. Pembuatan Silase

Akan tetapi, kandungan logam berat dan pestisida belum dilakukan. Hasil produk silase ini sudah pernah diujikan pada hewan ternak unggas (Osoro \& Meevootisom, 1986).

Sebagai sistem biologis, pembuatan silase tidak selalu bekerja dengan sempurna. Hal inilah yang sering sebagai penyebeb kegagalan dalam pembuatan silase. Selama fermentasi silase anaerobik, mikroorganisme mengonsumsi gula dan karbohidrat terlarut lainnya dalam bahan hijauan dan menghasilkan asam organik, seperti laktat dan asetat. Ini menurunkan $\mathrm{pH}$ dan menciptakan lingkungan agar silase yang dihasilkan dipertahankan (Hidayat, 2014). Fermentasi yang efisien diinginkan disebabkan dua alasan, yakni mengawetkan nutrisi untuk mengoptimalkan asupan dan kinerja ternak dan untuk meminimalkan bahan kering hijauan yang hilang dalam proses fermentasi dan pembusukan saat pemberian pakan. Kunci untuk membuat silase yang baik adalah potong pada kematangan hijauan, dalam hal ini eceng gondok dan sisa panen pada kelembapan yang tepat, potong dengan panjang yang tepat, gunakan inokulan secara sesuai, jaga agar tetap anaerob (tanpa oksigen) dengan mengisi silo dengan cepat, pengepakan yang memadai, tutup dan segel rapat dan segera dilakukan. Namun, terkadang hal-hal tersebut tidak kurang diperhatikan oleh klomtan. Hal ini mengakibatkan kehilangan masa fermentasi yang tinggi, kualitas nutrisi dan palatabilitas yang buruk, dan silase yang mudah rusak. Hal ini perlu menjadi perhatian agar di kemudian hari bisa mengetahui apa yang harus dilakukan dan diantisipasi dalam pembuatan silase.

Karakteristik silase hasil pengamatan langsung disajikan pada Tabel 3.

Tabel 3. Karakteristik Silase

\begin{tabular}{lll}
\hline \multicolumn{1}{c}{ Indikator } & Pre process & Post process \\
\hline $\begin{array}{l}\text { 1. Warna } \\
\text { bahan }\end{array}$ & Hijau & Coklat \\
\hline 2. Bau & Tidak berbau & Harum \\
\hline 3. Kondisi & Segar & $\begin{array}{l}\text { tidak } \\
\text { menggumpal, } \\
\text { bahan }\end{array}$ \\
& tersegregasi & $\begin{array}{l}\text { tidak berbau } \\
\text { busuk/berjamur }\end{array}$ \\
\hline
\end{tabular}

\section{SOP Pembuatan Biokompos.}

Tahap-tahap dalam pembuatan biokompos adalah sebagai berikut. (1) Air dimasukkan ke dalam bak/drum. Volume air yang diperlukan kurang lebih 200 L untuk setiap 1 ton bahan (jerami). (2) Biodekomposer dimasukkan ke dalam bak sesuai dosis yang diperlukan, lalu diaduk hingga tercampur merata. (3) Jerami disiapkan, apabila sudah terlalu kering, lakukan perendaman selama 4-6 jam, lalu dimasukkan jerami lapis demi lapis, disiramkan biodekomposer pada setiap lapis secara merata, dipadatkan setiap lapisan jerami dengan cara diinjak-injak pada cetakan bambu; setelah penuh, cetakan bambu dibuka dan ditutup dengan plastik. (4) Plastik diikat dengan tali dan diberi pemberat pada bagian atas plastik. Tumpukkan jerami dibiarkan selama 2-4 minggu. (5) Setelah diinkubasi 2 minggu, penutup plastik dibuka dan diamati penampilan fisiknya. 


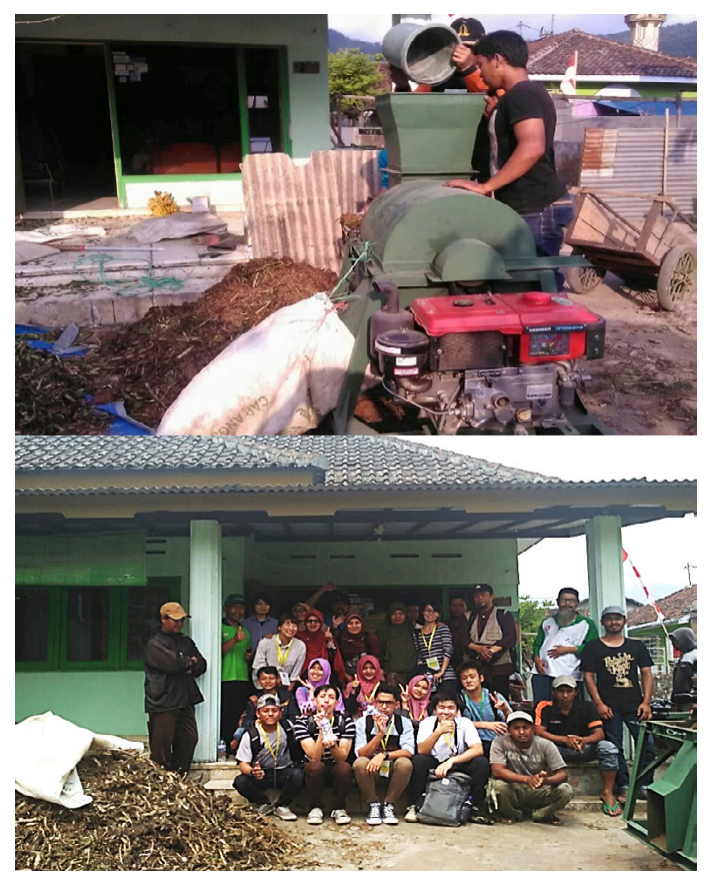

Gambar 5. Pembuatan Biokompos

Pengomposan berjalan baik apabila terjadi penurunan tinggi tumpukan, dipegang terasa panas, tidak berbau menyengat, dan jerami mulai melunak (Tabel 4).

Kompos berkualitas baik jika dalam pengamatan fisik terlihat sebagai berikut: berwarna coklat kehitamhitaman, lunak dan mudah dihancurkan, suhu tumpukan sudah mendekati suhu awal pengomposan, tidak berbau menyengat dan volume menyusut hingga kurang lebih setengahnya (Osoro, 2014). Analisis kualitas kompos harusnya juga dilakukan di laboratorium untuk mengetahui apakah sudah sesuai dengan standar kandungan $\mathrm{C} / \mathrm{N}$ rasio, $\mathrm{P}$ dan K (Wulandari et al., 2016: 34). Dari pendampingan yang dilakukan, ketika klomtan melakukan pembuatan kompos sendiri, mereka mengalami kegagalan. Hal ini terjadi karena tumpukan seresah kompos tidak mencapai volume minimal dan kurang mendapatkan cukup udara. Perlu juga membalik tumpukan secara teratur, baik itu di bak pengomposan maupun hanya berupa tumpukan seresah. Aerasi sangat penting, sekalipun mendapatkan aliran udara yang cukup di bagian atas karena pasokan oksigen di bagian bawah akan habis seiring waktu.

Tabel 4. Karakteristik Biokompos

\begin{tabular}{|c|c|c|}
\hline Indikator & Pre process & Post process \\
\hline $\begin{array}{l}\text { 1. Warna } \\
\text { bahan }\end{array}$ & $\begin{array}{l}\text { Coklat } \\
\text { kehijuan }\end{array}$ & Coklat tua kehitaman \\
\hline 2. $\mathrm{Bau}$ & Tidak berbau & $\begin{array}{l}\text { Harum dan tidak } \\
\text { menyengat }\end{array}$ \\
\hline $\begin{array}{l}\text { 3. Kondisi } \\
\text { bahan }\end{array}$ & $\begin{array}{l}\text { Segar } \\
\text { tersegregasi }\end{array}$ & $\begin{array}{l}\text { Lunak, tidak } \\
\text { menggumpal, tidak } \\
\text { berbau busuk/ } \\
\text { berjamur }\end{array}$ \\
\hline 4. Suhu & $\begin{array}{l}\text { Normal } \\
\left(26-28^{\circ} \mathrm{C}\right)\end{array}$ & $\begin{array}{l}\text { Tinggi } \\
\left(60-70^{\circ} \mathrm{C}\right)\end{array}$ \\
\hline
\end{tabular}

Kompos berkualitas baik jika dalam pengamatan fisik terlihat sebagai berikut: berwarna coklat kehitamhitaman, lunak dan mudah dihancurkan, suhu tumpukan sudah mendekati suhu awal pengomposan, tidak berbau menyengat dan volume menyusut hingga kurang lebih setengahnya (Osoro, 2014). Analisis kualitas kompos harusnya juga dilakukan di laboratorium untuk mengetahui apakah sudah sesuai dengan standar kandungan $\mathrm{C} / \mathrm{N}$ rasio, $\mathrm{P}$ dan K (Wulandari et al., 2016: 34). Dari pendampingan yang dilakukan, ketika klomtan melakukan pembuatan kompos sendiri, mereka mengalami kegagalan. Hal ini terjadi karena tumpukan seresah kompos tidak mencapai volume minimal dan kurang mendapatkan cukup udara. Perlu juga membalik tumpukan secara teratur, baik itu di bak pengomposan maupun hanya berupa tumpukan seresah. Aerasi sangat penting, sekalipun mendapatkan aliran udara yang cukup di bagian atas karena pasokan oksigen di bagian bawah akan habis seiring waktu.

\section{Pengadaan Tempat Simpan Silase dan Biokompos}

Pengadaan tempat khusus digunakan untuk pembuatan dan penyimpanan silase dan biokompos dan mesin pengering dan pencacah enceng gondok. Silase adalah pakan yang berasal dari hijauan, hasil samping 
pertanian atau bijian berkadar air tertentu yang telah diawetkan dengan cara disimpan dalam tempat kedap udara selama kurang lebih tiga minggu. Penyimpanan pada kondisi kedap udara tersebut menyebabkan terjadinya fermentasi pada bahan silase. Tempat penyimpanannya disebut silo. Silo bisa berbentuk horizontal ataupun vertikal. Silo yang digunakan pada peternakan skala besar adalah silo yang permanen, bisa berbahan logam berbentuk silinder atau pun lubang dalam tanah (kolam beton). Silo juga bisa dibuat dari drum atau bahkan dari plastik. Prinsip dari silo memungkinkan untuk memberikan kondisi anaerob pada bahan agar terjadi proses fermentasi. Kompos merupakan bahan yang apabila berubah, tidak dapat kembali ke keadaan semula (Ireversible). Apabila kompos mengering, unsur hara yang terkandung di dalamnya akan ikut hilang bersama dengan air dan apabila kompos ditambahkan air kembali, maka unsur hara yang hilang tadi tidak dapat kembali lagi. Oleh karena itu, untuk penyimpanan kompos perlu dihindarkan dari air hujan.

Pelatihan tentang manajemen pemanfaatn limbah pertanian dan gulma enceng gondok dilakukan untuk produksi mandiri dan potensi usaha sampingan. Dengan demikian, semua limbah pertanian dan gulma enceng gondok yang dihasilkan dari usaha tani-ternak dapat

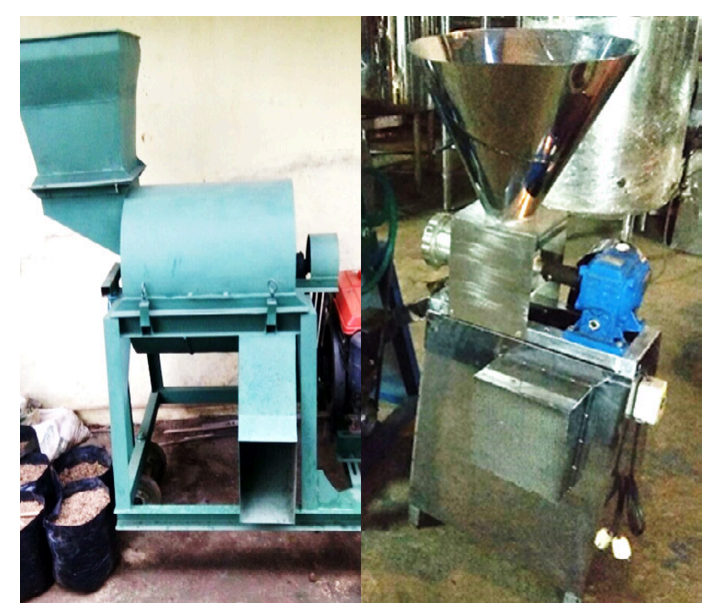

Gambar 6. Peralatan pelatihan didaur ulang sehingga tidak ada lagi limbah yang tidak termanfaatkan (zero waste product). Pelaksanaan kegiatan dalam program tersebut selain ramah lingkungan, juga meningkatkan efisiensi produksi dalam usaha tani-ternak.

Pengadaan tempat khusus untuk pembuatan dan pemyimpanan silase dan biokompos sudah disiapkan oleh kelompak tani binaan; demikian pula dengan mesin pencacah dan pemeras enceng gondok serta mesin pembuat konsentrat dari silase (Gambar 6). Tempat khusus penyimpanan produk dan peralatan berada di sebelah balai pertemuan (Gambar 7).

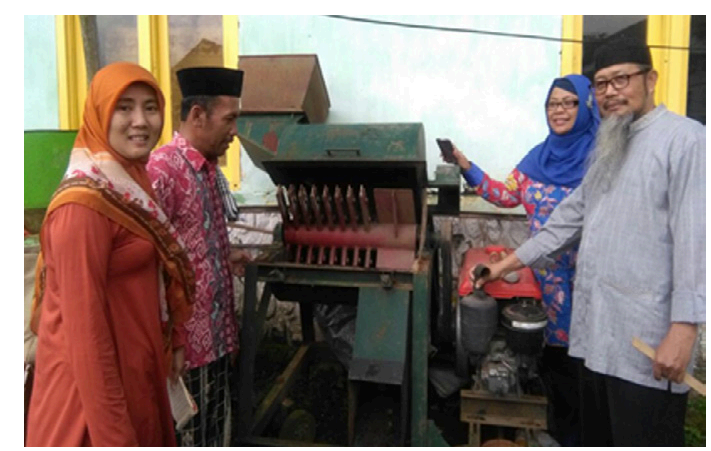

Gambar 7. Lokasi penyimpanan peraatan dan produk

Mesin pengepres eceng gondok diletakkan di gedung pertemuan Dusun Gading, sedangkan lokasi produksi adalah di pondok kelompok tani Lestari Jaya Makmur untuk keamanan dan pemantauan.

Menurut Wulandari et al., (2016: 34), kandungan pupuk organik dari eceng gondok adalah memiliki $\mathrm{C}$ organic $31 \mathrm{sd}$ $35 \%$; Nitrogen sebesar $1.5 \mathrm{sd} 2.2 \% ; \mathrm{P}_{2} \mathrm{O}_{5}$ sebesar 0.47 sd $0.72 \% ; \mathrm{K}_{2} \mathrm{O}$ sebesar $2.2 \mathrm{sd} 5.5 \%$; kadar air sebesar $14.9 \mathrm{sd}$ $29 \%$; dan $\mathrm{pH}$ berkisar $6.4 \mathrm{sd} 6.8$. Untuk mempercepat proses pembuatan pupuk organik tersebut diperlukan dekomposer (starter) (Lestari et al., 2018: 24). Pemberian pupuk organik eceng gondok dapat meningkatkan produksi sawi (Patra et al., 2019); Aglonema (Yuliatin et al., 2018: 28) dan meningkatkan tingakt ekonomi masyarakat (Kusrinah et al., 2016: 27); Prihartinigntyas et al., 2020: 
114).

\section{Pelatihan tentang Manajemen}

Usaha pemanfaatan limbah pertanian dan gulma enceng gondok untuk produksi mandiri pakan ternak dan biokompos sangat berotensi sebagai usaha sampingan selain usaha utamanya bercocok tanam di bidang pertanian. Semua limbah pertanian dan gulma enceng gondok yang dihasilkan dari usaha tani-ternak dapat didaur ulang sehingga tidak ada lagi limbah yang tidak termanfaatkan (zero waste product).

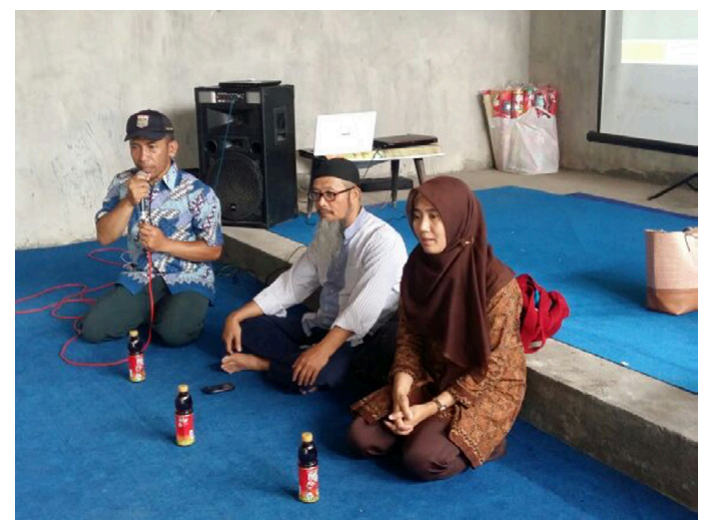

Gambar 8. Pelatihan manajemen

Dalam pelatiham manajemen ini (gambar 8) kelompok tani diberikan materi dasar 2 manajemen usaha, pemasaran usaha, dan perluasan jaringan pemasaran.

\section{Monitoring dan Evaluasi}

Tujuan dari kegiatan monitoring dan evaluasi ini adalah mengukur tingkat keberhasilan program yang telah diterapkan terhadap kelompok tani Teman Sejati di dusun gading dan desa Kaumrejo. Cara yang ditempuh adalah dengan mengedarkan questioner kepada anggota kelompok tani yang sudah melakukan pendampingan dan pelatihan. Hasil monitoring ini diharapkan dapat mencapai target yang telah ditetapkan, terutama peningkatan kesejahteraan dari kelompok tani. Kuesioner ini dibagikan pada anggota kelompok tani yang mengikuti pelatihan dan yang tidak mengikutinya.
Monitoring dan evaluasi ini adalah upaya untuk melihat ketercapaian output dari kegiatan ini yang dapat dilihat dari beberapa indikator capaian sebagai berikut (Tabel 5).

Tabel 5. Hasil Evaluasi dan Monitoring

\begin{tabular}{|c|c|c|c|}
\hline & Indikator & $\begin{array}{c}\text { Diluar } \\
\text { Anggota }\end{array}$ & $\begin{array}{c}\text { Anggota } \\
\text { Kelompok Tani }\end{array}$ \\
\hline 1 & $\begin{array}{l}\text { Pemahaman } \\
\text { terhadap } \\
\text { Pemilihan dan } \\
\text { penggunaan } \\
\text { bahan baku }\end{array}$ & $20 \%$ & $80 \%$ \\
\hline 2 & $\begin{array}{l}\text { Pemahaman } \\
\text { terhadap } \\
\text { penggunaan } \\
\text { perlatan }\end{array}$ & $10 \%$ & $89 \%$ \\
\hline 3 & $\begin{array}{l}\text { Pengetahuan } \\
\text { tentang Proses } \\
\text { dan tahapan } \\
\text { pembuatan } \\
\text { silase (pakan } \\
\text { ternak) dengan } \\
\text { konsep zero } \\
\text { waste produk }\end{array}$ & $5 \%$ & $85 \%$ \\
\hline & $\begin{array}{l}\text { Pengetahuan } \\
\text { tentang } \\
\text { keuntungan } \\
\text { dan kelebihan } \\
\text { teknik } \\
\text { fermentasi }\end{array}$ & $10 \%$ & $81 \%$ \\
\hline & $\begin{array}{l}\text { Pemgetahuan } \\
\text { tentang nilai } \\
\text { tambah produk }\end{array}$ & $25 \%$ & $86 \%$ \\
\hline
\end{tabular}

Dari Tabel 5 terlihat bahwa secara umum pengetahuan tentang teknogi yang diintroduksikan bagi anggota kelompok tani lebih tinggi jika dibandingkan dengan nonanggota kelompok tani. Pengetahuan anggota kelompok tani berkisar antara 81 s.d. $89 \%$, sedangkan yang di luar kelompok indikator capaiannya hanya berkisar 5 s.d. $25 \%$.

\section{Kesimpulan dan Saran}

\section{Kesimpulan}

Tujuan dari kegiatan ini telah tercapai, yaitu teknologi zero waste product mampu diadopsi oleh anggota kelompok tani dengan rata-rata capaian pengetahuan sebesar $85 \%$ melalui pelatihan dan pendampingan pembuatan 
silase dan biokompos dari gulma eceng gondok. Akan tetapi, karena melibatkan teknologi fermentasi, kegiatan ini harus didampingi terus-menerus dalam waktu yang panjang dan tidak cukup pada program kegiatan 6 bulan. Untuk produksi silase, hasil produksi klomtan kurang memenuhi standar karena banyak faktor diabaikan atau kurang diperhatikan oleh klomtan. Sementara itu, untuk pembuatan biokompos, relatif berhasil, hanya saja volume seresah bahan dasar kompos kurang dari syarat minimal sehingga panas yang harus dicapai dalam pengomposan tidak terjadi.

\section{Saran}

Untuk kegiatan selanjutnya perlu dilanjutkan upaya pendampingan produksi terutama silase agar mencapai standar minimal pakan ternak yang bergizi dan pendampingan secara regular agar usaha ini dapat ditingkatkan skala produksinya.

\section{DAFTAR PUSTAKA}

Anonymous. (2013). Profil Desa Kaumrejo, Kecamatan Ngantang, Kabupaten Malang, Laporan Kerja Tahunan Desa Kaumrejo

Departemen Perindustrian. (1992). Pengembangan Sumberdaya Manusia Industri yang Profesional dalam Menyongsong PJP II, Jakarta: Departemen Perindustrian.

Hayashi, Y., Manuwoto, S., \& Hartono, S. (2003). Sustainable Agriculture in Rural Indonesia, Yogyakarta: Gajah Mada University Press.

Hidayat, N. (2014). Karakteristik dan Kualitas Silase Rumput Raja Menggunakan berbagai Sumber dan Tingkat Penambahan Karbohidrat Fermentable, Jurnal Agripet, Vol. 14, No. 1, pp. 42-49. http://dx.doi.org/10.17969/agripet. v14i1.1204

Juliani, R., Simbolon, R.F.R., Sitanggang, W.H., \& Aritonang, J.B. (2017).
Pupuk organic eceng gondok dari Danatu Toba, Jurnal Pengabdian Kepada Masyarakat, Vol. 23, No. 1, pp. 220-224. https://doi. org/10.24114/jpkm.v23i1.6637

Kusrinah, N. A., \& Hayati, N. (2016). Pelatihan dan Pendampingan pemenfaatn eceng gondok (Eichornia crassipes) menjadi pupuk kompos cair untuk mengurangi pencemaran air dan meninghktakan ekonomi masyarakat desa Karangkimpul Kelurahan Kaligawe Kecamatan Gayamsari Kotamadya Semarang, DIMAS, Vol. 16, No. 1, pp.27-48.

Lestari, A.A., Muslimin, M,B., Rosmiati, \& Mahi, R. (2018). Pelatihan pemanfaatn gulma eceng gondok. sebagai pupuk alternative, Journal of Character Educational Society, Vol. 1, No. 2, pp. 24-29.

Osoro, T.W., \& Meevootisom, V. (1986). Biological Treatment of Straw for Animal Feed Proceding: Conference Firt Asean Science and Technology Week. Putra World Trade Centre. Kuala Lumpur, Vol. II.

Osoro, N., Muoma, J.O., Amoding, A., Mukaminega, D., Muthini, M., Ombori \& Maingi, J.M. (2014). Effects of Water Hyacinth (Eichhornia crassipes mart.] solms) Compost on Growth and Yield Parameters of Maize ( Zea mays), British Journal of Applied Science \& Technology, Vol. 4, No. 4, pp. 617-633.

Patra, M., Kartini., N.L., \& Soniari.., N.N. (2019). Pengaruh pupuk organic eceng gondok dan pupuk hayati terhadap sifat biologi, pertumbihan dan hasil tanaman sawi (Brassica juncea). E-Jurnal Agroekoteknologi Tropika, Vol.8, No.1, pp.118-126.

Prihartiningtyas, E., Asysyfa \& Susilawati, (2020). Pemanfaatna eceng gondok (Eichornia crassipes) 
untuk mengurangi pencemaran air dan meningkatkan ekonomi masyarakat desa Tungkaran, Prosiding Seminar Nasional Pengabdian Kepada Masyarakat, Vol. 2, pp. 114-120.

Sittadewi, E.H. (2007). Pengolahan Bahan organic eceng gindok menjadi media tumbuh untuk mendukung pertanian organic, Jurnal Ternik Lingkungan, Vol.8, No.3, pp.229-234.

Wulandari, D.A, Linda, R., \& Turnip, M. (2016). Kualitas Kompos dari Kombinasi Eceng Gondok (Eichornia crassipes Mart. Solm) dan Pupuk Kandang Sapi dengan Inokulan Trichoderma harzianum L, Jurnal Protobiont, Vol.5, No.2, pp.34-44.

Yuliatin, E., Sari, Y.P., \& Hendra, M. (2018). Efektivitas pupuk organic cair dari eceng gondok (Eichornia crassipes (Mart), Solm) untuk pertumbuhan dan kecerahan warna merah daun Aglonema 'Lipstik', Jurnal Biotropika, Vol.6, No.1, pp.28-34. 